\title{
APLIKASI PRINSIP-PRINSIP TERKAIT BUKTI ILMIAH (SCIENTIFIC EVIDENCE) DI AMERIKA SERIKAT DALAM PEMBUKTIAN PERKARA PERDATA LINGKUNGAN DI INDONESIA
}

\author{
Windu Kisworo ${ }^{69}$
}

\begin{abstract}
Abstrak
Pengaturan terkait bukti ilmiah dalam penanganan kasus lingkungan di pengadilan di Indonesia masih bersifat umum. Sementara di Amerika Serikat, aturan yang sangat rinci tentang bukti ilmiah telah lama ada dan dipraktekkan dalam pembuatan putusan pengadilan. Tulisan ini akan mengidentifikasi tantangan dalam mendayagunakan bukti ilmiah dalam penanganan kasus lingkungan di pengadilan di Indonesia, dengan mengambil pelajaran dari pengaturan dan metode yang digunakan di Amerika. Tulisan ini menggunakan pendekatan doktrinal terhadap peraturan dan putusan. Tulisan ini fokus pada dua hal yang Penulis anggap relevan dengan konteks Indonesia saat ini: aspek keberadaan metode ilmiah yang valid serta pengetahuan khusus yang mendasari pendapat ahli. Tulisan ini menyimpulkan bahwa hukum dan peraturan di Indonesia memuat berberapa prinsip-prinsip umum yang ada di Amerika Serikat. Namun demikian belum dianggap cukup dan diperlukan penguatan hukum terkait dua hal diatas.
\end{abstract}

Kata Kunci: bukti ilmiah, metode ilmiah, pengetahuan khusus

\begin{abstract}
The Indonesian regulations concerning the scientific evidence in handling environmental cases in court are still broad. Meanwhile, the United States has a very long established and detail guideline on scientific evidence both under statues and cases laws. This article aims to identify challenges in utilising scientific evidence in handling environmental cases in Indonesia by taking a lesson from the United States. This article will employ a doctrinal approach to specific laws, regulation and court decision. This article will only focus on two aspects relevant for Indonesia: the existing of the valid scientific method and specialised knowledge of an expert witness. This article concludes that the existing law and regulation contains some general principle from the United States. However, it is not adequate. Policy reforms need to further research on the above two aspects.
\end{abstract}

Keywords: scientific evidence, scientific method, specialised knowledge

${ }^{69}$ Penulis saat ini sedang menyelesaikan studi Doktoral di Macquarie Law School, University of Macquarie, Australia. 


\section{Pendahuluan}

Bukti ilmiah memiliki peranan yang sangat penting dalam penanganan kasus lingkungan. Bukti ilmiah diperlukan untuk membuktikan adanya hubungan kausalitas (sebabakibat) antara perbuatan yang melanggar hukum dengan dampak yang ditimbulkan. ${ }^{70}$ Tingkat kesuksesan penanganan perkaraperkara lingkungan di pengadilan seringkali bergantung pada adanya bukti ilmiah dan bukti teknis lainnya. ${ }^{71}$

Hukum lingkungan, baik di tingkat nasional maupun internasional, merupakan bidang hukum yang sangat kompleks. Pada saat yang sama, ilmu pengetahuan, ekonomi dan teknologi terus berubah dengan cepat, mendahului perkembangan hukum lingkungan itu sendiri. ${ }^{72}$ Oleh karena itu, hanya mengikuti perkembangan hukum lingkungan tanpa disertai pemahaman sains tidaklah cukup bagi penegak hukum. ${ }^{73} \mathrm{Hal}$ ini terutama berlaku bagi hakim dalam menangani perkara lingkungan di pengadilan, khususnya dalam proses pembuktian. Para hakim perlu memiliki pengetahuan yang memadai tentang sains dan metodologi ilmiah untuk menghasilkan keputusan yang tepat. ${ }^{74}$

Dalam kurun waktu 15 (lima belas) tahun terakhir, bukti ilmiah telah banyak didayagunakan dalam berbagai perkara lingkungan di pengadilan di Indonesia. ${ }^{75} \mathrm{Di}$ satu sisi, perkembangan

${ }^{70}$ Valerie Mike, Understanding Uncertainties in Medical Evidence: Profesional and Public Responsibilities, dalam Acceptable Evidence: Science and Value in Risk Management, 118 (Deborah G. Mayo \& Rachelle D. Holladers eds., 1991) sebagaimana dikutip oleh Keum J Park, "Judicial Utilization of Scientific Evidence in Complex Environmental Torts: Redefining Litigation Driven," 7(2) (1996) Fordham Environmental Law Review, hlm. 486.

${ }^{71}$ Keum J Park, op. cit., hlm. 483.

72 George Pring and Catherine Pring, Environmental Courts \& Tribunals - A Guide for Policy Makers (UNEP) | ELAW (2016), hlm. 46

${ }^{73}$ George Pring and Catherine Pring, Greening Justice: Creating \& Improving Environmental Courts \& Tribunals (The Access Initiative, 2009), hlm. 73.

${ }^{74}$ Katherine Bishop, Science Advance so Quickly Nowadays. We can't just Count Scientific Noses', Leap of Science Create Quandaries on Evidence, N.Y. TIMES, April 6, 1990, Sebagaimana dikutip oleh Keum J Park, 'Judicial Utilization of Scientific Evidence in Complex Environmental Torts: Redefining Litigation Driven' 7(2) Fordham Environmental Law Review, hlm 487.

75 Periode ini dimulai pada tahun 2000-an pada saat Mahkamah Agung mulai melakukan pelatihan hukum lingkungan bagi hakim dan penegak hukum lainnya. Berberapa putusan kasus kebakaran 
ini menunjukan adanya harapan bagi perbaikan putusan perkara lingkungan, ${ }^{76}$ namun perlu diakui masih terdapat beberapa putusan pengadilan yang dianggap bermasalah.77 Secara umum dapat dikatakan bahwa masih banyak tantangan untuk mendayagunakan bukti ilmiah dalam penanganan perkara lingkungan. Hakim masih menghadapi kesulitan untuk memaknai bukti ilmiah sebagai bukti hukum karena terbatasnya pemahaman hakim tentang sains. ${ }^{78}$ Padahal pemahaman hakim tentang sains sangat diperlukan untuk menentukan dan mengaplikasikan fakta-fakta ilmiah ke dalam kerangka hukum, sehingga dapat dihasilkan suatu putusan yang tepat dan akuntabel. 79

Menyadari kendala tersebut, Mahkamah Agung telah melakukan berbagai inisiatif untuk memperbaiki kualitas putusan, antara lain dalam bentuk pelatihan hukum lingkungan bagi para penegak hukum. ${ }^{80}$ Dalam pelatihan tersebut, materi tentang bukti ilmiah dan bukti hukum merupakan materi yang wajib diberikan kepada para hakim. Upaya lebih lanjut terus dilakukan dalam skema sistem

hutan diantaranya kasus Surya Panen Subur (2013), Kalista Alam (2015), Jatim Jaya Perkasa (2016), Bumi Mekar Hujau (2016), Waringin Argo Jaya (2017), Nasional Sago Prima (2017).

${ }^{76}$ Putusan yang dianggap sebagai 'putusan landmark' adalah putusan kasus Mandalawangi (2003) yang menerapkan prinsip precautionary principle, Putusan Kalista Alam (2015) dimana pengadilan mendayagunakan bukti ilmiah seperti bukti hotpsot dari citra satelit dalam pembuktian, serta Putusan kasus kebakaran hutan PT. Waringin Argo Jaya (2017) dimana hakim menerapkan prinsip strict liability dalam hal pembuktian.

77 Yenrizal, "Opini: Berkaca Pada Putusan Kasus PT. BMH", http://www.mongabay.co.id/2016/01/13/opini-berkaca-pada-putusan-kasus-pt-bmh/, diakses pada 12 September 2018.

78 MVT, "Hakim Seringkali Abaikan Bukti Ilmiah,"
http://www.hukumonline.com/berita/baca/lt4d4cf9774f064/hakim-seringkali-abaikan-buktiilmiah-, diakses pada 23 Juli 2018.

${ }^{79}$ Wawancara dengan Justice Brian J. Preston, Ketua Pengadilan Land \& Environment Court, New South Wales, Australia, 7 Maret 2018.

80 Pelatihan hukum lingkungan bagi para penegak hukum dilakukan sejak tahun 2000 oleh Mahkamah Agung berkerjasama dengan beberapa lembaga hukum lingkungan di Indonesia dan Australia. Sejak dibentuk sistem sertifikasi hakim lingkungan pada tahun 2013 telah dilatih sebanyak kurang lebih 1500 peserta yang terdiri dari 600 hakim. 
sertifikasi hakim lingkungan. ${ }^{81}$ Sistem ini mengatur bahwa perkara lingkungan ditangani oleh hakim yang telah lulus sertifikasi. Hakim yang telah mendapat sertifikat diharapkan dapat menerapkan ilmu tentang bukti ilmiah dan bukti hukum yang telah mereka peroleh selama pelatihan.

Selain itu Mahkamah Agung juga menyusun pedoman penanganan perkara lingkungan yang memuat ketentuan tentang bukti ilmiah dan ahli. ${ }^{82}$ Namun demikian, pada banyak kasus, Hakim memberikan bobot yang lebih berat kepada bukti selain bukti ilmiah dalam membuktikan pencemaran/perusakan lingkungan. 83 Hakim yang berlatar belakang hukum masih kesulitan memahami data-data ilmiah yang disampaikan oleh ahli untuk dikonversi menjadi faktahukum. ${ }^{84}$

Tulisan ini bertujuan untuk melihat sejauh mana aplikasi prinsip terkait bukti ilmiah di Amerika Serikat dalam proses pembuktian perkara perdata lingkungan di Indonesia. Penulis menyadari terdapat banyak aspek yang perlu dipertimbangkan dalam melakukan perbandingan hukum. ${ }^{85}$ Menjadikan model dan pilihan desain (ketentuan hukum) dari satu negara ke negara lain membutuhkan analisis yang mendalam untuk memastikan bahwa model dan pilihan desain tersebut (aplikasi) sesuai dengan kondisi politik dan kondisi khusus lainnya dari suatu yurisdiksi. ${ }^{86}$ Oleh karena itu, tulisan ini hanya merupakan penelitian awal yang

81 Pada tahun 2013, untuk memastikan keberlanjutan dari pelatihan ini dibentuk Sistem Sertifikasi Hakim Lingkungan oleh Mahkamah Agung dimana kasus lingkungan ditangani oleh hakim yang telah memperoleh sertifikasi.

82 Indonesia, Mahkamah Agung, Keputusan Ketua tentang Pedoman Penanganan Kasus Lingkungan, SK KMA No. 36/KMA/SK/II/2013.

83 Wawancara dengan Fauzul Abrar, S.H pada tanggal 17 Juli 2018.

84 Wawancara dengan Raynaldo Sembiring, Peniliti pada Indonesian Center for Environmental Law pada tanggal 5 Juli 2018.

85 Terkait penegakan hukum lingkungan, Pring menyebutkan faktor-faktor tersebut termasuk diantaranya kemauan politik dari pemerintah, tingkat korupsi, dan dorongan masyarakat untuk pertanggungjawaban lingkungan. Lihat George Pring and Catherine Pring, Greening Justice: Creating E Improving Environmental Courts \& Tribunals (The Access Initiative, 2009), hlm. 19.

86 George Pring and Catherine Pring, op. cit., hlm. 19. 
memerlukan penelitian lanjutan yang lebih mendalam dengan mempertimbangkan aspek-aspek tersebut.

Sebagai analisis awal, tulisan ini terbatas pada 2 (dua) aspek dalam pembuktian dan penggunaan bukti ilmiah yang dianggap penting, berdasarkan pengalaman pendayagunaan bukti ilmiah dalam perkara lingkungan di pengadilan di Amerika Serikat. Kedua aspek tersebut adalah: pertama, aspek keberadaan metode ilmiah yang valid; kedua, pengetahuan khusus yang mendasari pendapat ahli. Namun demikian, tulisan ini juga akan mengidentifikasi beberapa hal yang perlu diperkuat dalam mendayagunakan bukti ilmiah di pengadilan, baik dari segi pengaturan maupun praktek dalam penanganan kasus perdata lingkungan sebagai masukan untuk penelitian lanjutan.
Bagian pertama tulisan ini akan menjelaskan hubungan antara ilmu pengetahuan dan hukum. Tujuan yang diharapkan adalah untuk meberikan pemahaman tentang kedudukan bukti ilmiah dalam suatu perkara. Bagian kedua akan menjelaskan secara singkat prinsip-prinsip penanganan perkara lingkungan di Amerika Serikat, khususnya pedoman bagi hakim untuk menilai apakah suatu bukti ilmiah adalah bukti yang dapat diandalkan (reliable). Bagian ini akan digunakan sebagai kerangka analisis untuk mengidentifikasi berbagai hal yang perlu diperkuat dalam mendayagunakan bukti ilmiah dalam penanganan kasus perdata lingkungan di pengadilan di Indonesia. Dalam proses identifikasi ini, bagian ketiga akan menganalisis kebijakan serta pendayagunaan bukti ilmiah dalam perkara Jatim Jaya Perkasa. ${ }^{87}$ Pada bagian akhir, tulisan ini akan menganalisis aplikasi prinsip Daubert dalam proses

${ }^{87}$ Pengadilan Negeri Jakarta Utara, Putusan No. 108/Pdt.G/2015/PN.Jkt.Utr., Menteri Lingkungan Hidup dan Kehutanan Republik Indonesia v. PT. Jatim Jaya Perkasa; lihat juga Pengadilan Tinggi Jakarta, Putusan No. 727/PDT/2016/PT.DKI, Menteri Lingkungan Hidup dan Kehutanan Republik Indonesia v. PT. Jatim Jaya Perkasa. 
APLIKASI PRINSIP-PRINSIP TERKAIT BUKTI ILMIAH (SCIENTIFIC EVIDENCE) DI AMERIKA SERIKAT DALAM PEMBUKTIAN PERKARA PERDATA LINGKUNGAN DI INDONESIA

pembuktian perkara perdata Misalnya terhadap pertanyaan lingkungan di Indonesia serta bagaimana kita dapat meyakini bahwa memberikan beberapa rekomendasi suatu teori atau teknik bukan bagi kebijakan dan penguatan kapasitas penegak hukum, khususnya hakim, dalam mendayagunakan bukti ilmiah dalam penanganan kasus lingkungan di pengadilan.

\section{Bukti Ilmiah dalam Proses Pembuktian di Pengadilan}

Pendayagunaan bukti ilmiah dalam proses pembuktian di pengadilan erat kaitannya dengan sains. Kamus Besar Bahasa Indonesia mendefiniskan sains sebagai pengetahuan sistematis yang diperoleh dari sesuatu observasi, penelitian, dan uji coba yang mengarah pada penentuan sifat dasar dari sesuatu yang sedang dipelajari atau diselidiki. ${ }^{88}$ Secara sederhana, sains dapat juga dipahami dengan melihat perannya dalam menjawab pertanyaanpertanyaan yang sifatnya mendasar. 89 merupakan sekedar keyakinan atau opini, melainkan merupakan sains? Jawaban yang sifatnya umum dari sudut pandang ilmiah adalah dengan mendasarkannya pada suatu 'metode ilmiah' ${ }^{90} \mathrm{Hal}$ ini menunjukan bahwa pendapat para ilmuwan diakui karena kesimpulan mereka (seharusnya) diperoleh berdasarkan metode ilmiah yang dapat dipertanggungjawabkan. ${ }^{91}$ Dengan demikian, paling tidak ada dua hal yang penting untuk diperhatikan ketika mendiskusikan sains. Pertama, mendiskusikan sains harus mempertimbangkan fakta bahwa tidak mudah untuk menentukan sesuatu adalah ilmiah (scientific) atau tidak - hal ini dikenal sebagai masalah demarkasi. ${ }^{92} \quad$ Kedua, tingkat kekhususan dalam ilmu-ilmu tertentu begitu luas sehingga tidak ada seorangpun yang dapat mampu

\footnotetext{
${ }^{88}$ Kamus Besar Bahasa Indonesia Daring, https://kbbi.web.id/sains, diakses 10 September / 2018.

${ }^{89}$ Keum J Park, op. cit., hlm. 483.

90 Ibid.

${ }^{91}$ Ibid.

92 Ibid.
} 
memahami semua hal yang perlu diketahui tentang satu bidang sains. ${ }^{93}$

Di dalam praktek pembuktian di pengadilan, hubungan antara sains dan hukum sangat kompleks. Beberapa ahli berpendapat kompleksitas tersebut terjadi karena tujuan yang melekat pada keduanya. Hukum dan sains kadang-kadang memiliki tujuan yang saling bertentangan, karena masingmasing telah berkembang sebagai reaksi terhadap kebutuhan sosial dan intelektual yang berbeda. ${ }^{94}$ Tujuan hukum di satu sisi dianggap sebagai sarana untuk menyelesaikan konflik manusia secara adil, sementara tujuan sains di sisi lain, dipahami sebagai upaya untuk mencari 'kebenaran'.95 Oleh karena itu, tujuan untuk mencapai 'keadilan' dari sudut pandang hukum tidak sama dengan menemukan kebenaran 'hasil yang valid secara ilmiah' dari sudut pandang sains. ${ }^{96} \mathrm{Di}$ dalam proses penanganan perkara di pengadilan, ketidakcocokan antara sains dan hukum ini seringkali terjadi. Para ahli di satu sisi mempunyai kebutuhan untuk menjelaskan adanya suatu ketidakpastian (uncertainty), sedangkan pengacara di sisi lainnya melihat proses pemeriksaan tersebut sebagai kesempatan untuk melemahkan nilai bukti ilmiah, terutama jika hal itu dianggap menguntungkan mereka. ${ }^{97}$

Mengingat hal tersebut hakim perlu memiliki kemampuan untuk menilai suatu bukti ilmiah. Dalam perkara-perkara tertentu, hakim dapat mengandalkan kemampuannya sendiri untuk menilai bukti ilmiah tersebut. Namun, dalam perkara-perkara lingkungan yang sulit dan kompleks, besar kemungkinan hakim

93 Ibid.

${ }^{94}$ Ibid.

95 John I. Thornton, Uses and Abuses of Forensic Science, in Science and Law: An Essential Alliance 79, 86 (William A. Thomas, ed., 1983) sebagaimana dikutip dalam Keum J Park, "Judicial Utilization of Scientific Evidence in Complex Environmental Torts: Redefining Litigation Driven," Fordham Environmental Law Review, hlm. 494.

96 Richard L Markus, "Discovery Along the Litigation/Science Interface," Brooklyn Law Review Vol. 57 (1991), hlm. 384.

97 April Muirden and John Bailey, "Presenting Scientific Evidence in Environmental Court Cases: How Science and Law Meet," Environmental Planning and Law Journal, Vol. 25 hlm. 12. 
memerlukan bantuan ahli untuk menilai bukti ilmiah. Dalam hal demikian, hakim membutuhkan ahli yang memiliki pengetahuan khusus yang relevan dengan perkara yang sedang diperiksa. Pertanyaannya kemudian, apakah yang dimaksud dengan 'pengetahuan khusus' (specialised knowledge)? Dalam kondisi seperti apa pengadilan membutuhkan ahli yang memiliki 'pengetahuan khusus'? Pertanyaan ini hanya sebagian kecil dari pertanyaan penting yang timbul dalam perkara lingkungan yang melibatkan penggunaan bukti ilmiah, ketidakpastian (uncertainty) dan efek ekologi yang timbul yang tidak dapat dipulihkan (irreverseable effect to environment).

\section{Pengaturan tentang Bukti Ilmiah di Amerika Serikat}

Berbagai negara telah mengatur tentang peran bukti ilmiah dalam proses pembuktian di pengadilan. Salah satu negara yang dianggap memiliki aturan dan sistem pembuktian yang ketat dan rinci dalam perkara lingkungan, terutama yang berkaitan dengan persyaratan diterimanya bukti ilmiah (admissibility), adalah Amerika Serikat. ${ }^{98}$ Selain dalam bentuk aturan tertulis, sistem hukum di Amerika Serikat juga mengakui putusan hakim sebagai sumber hukum.

98 Selain Amerika, sistem di Australia juga memuat pengaturan secara khusus terkait bukti ilmiah, khususnya dalam menentukan diterimanya pendapat ahli terkait sains. Pasal 79 dari Evident Act mengatur bahwa: 'If a person has specialised knowledge based on the person's training, study or experience, the opinion rule does not apply to evidence of an opinion of that person that is wholly or substantialy based on that knowledge'. Ada tiga hal yang menjadi elemen atau kondisi dari ketentuan terkait 'pengetahuan khusus' di atas untuk menentukan suatu pendapat ahli dapat diterima sebagai suatu bukti. Pertama, ahli yang dihadirkan harus memiliki 'pengetahuan khusus'. Kedua, pengadilan menilai bahwa saksi memperoleh pengetahuan khusus tersebut berdasarkan pelatihan, studi atau pengalaman tertentu. Pada bagian ini, pengadilan biasanya mempertanyakan kualifikasi pendidikan saksi, keanggotaan ahli dalam masyarakat yang relevan dengan pengetahuan khusus, publikasi yang relevan, pengalaman sebagai saksi, dan sebagainya Ketiga, bahwa opini yang disampaikan didasarkan oleh keahlian yang dimiliki ('is wholly or substantially based on that knowledge'). Bagian ini mengharuskan pengadilan untuk menilai apakah ahli memiliki 'pengetahuan khusus' (a body of special knowledge), yang dapat memberikan dasar untuk menyampaikan pendapat yang relevan. 


\section{A. Rule 702, Federal Rules of Evidence}

Di Amerika Serikat, bukti ilmiah diatur dalam Federal Rule of Evidence, Rule 702 yang berbunyi:

"A witness who is qualified as an expert by knowledge, skill, experience, training, or education may testify in the form of an opinion or otherwise if:

a) the expert's scientific, technical, or other specialized knowledge will help the trier of fact to understand the evidence or to determine a fact in issue;

b) the testimony is based on sufficient facts or data;

c) the testimony is the product of reliable principles and methods; and

d) the expert has reliably applied the principles and methods to the facts of the case. ${ }^{99}$

Ketentuan tersebut pada prinsipnya menyatakan bahwa seorang saksi yang memiliki keahlian berdasarkan pengetahuan, keterampilan, pengalaman, pelatihan atau pendidikan yang ia miliki, dapat menjadi ahli dan mengemukakan pendapatnya di pengadilan apabila:

a) pengetahuan ilmiah, pengetahuan teknis, dan pengetahuan khusus lainnya yang dimiliki ahli dimaksud dapat membantu hakim dalam mengungkap fakta, untuk memahami bukti atau menentukan fakta dalam suatu perkara;

b) pendapat ahli didasarkan pada fakta atau data yang memadai;

c) pendapat ahli didasarkan pada prinsip dan metode ilmiah yang benar dan dapat diandalkan;

d) ahli menerapkan prinsip dan metode ilmiah tersebut dalam proses pembuktian, untuk mengungkapkan fakta dalam perkara yang sedang diperiksa.

Di dalam kasus Cano v. Everest Mineral Corp. ${ }^{100}$, berberapa Penggugat mempermasalahkan penyakit kanker yang diakibatkan dari paparan Uranium-238 yang bersumber dari tambang uranium yang dimiliki oleh Everest Mineral di sekitar tempat tinggal mereka. ${ }^{101}$ Penggugat mendalilkan bahwa salah satu biji uranium jatuh ke

\footnotetext{
99 Amerika Serikat, Federal Rules of Evidence, Rule 702.

100 D. Tex, Cano v. Everest Mineral Corp., 362 F. Supp.2d 814 (2005).

101 Ibid.
} 
jalan dan terlindas oleh truk yang sedang lewat. Hal ini mengakibatkan penyebaran debu uranium dan kontaminasi pada makanan dan sumber air.102 Pengadilan Wilayah Western Texas meminta kepada penggugat untuk membuktikan bahwa paparan debu uranium tersebut adalah penyebab dari masalah kesehatan mereka (dalam kasus ini adalah penyakit kanker). Hanya satu dari ahli yang disampaikan oleh penggugat yang memberikan kesaksian tentang hubungan kausalitas tersebut. Dr. Malin Dollinger dengan metodologi baru yang dia ciptakan menunjukan bahwa debu uranium adalah faktor yang paling dominan terhadap kanker. ${ }^{103}$ Terkait dengan Rule 702, hakim menyetujui latar belakang Dr. Malin Dollinger dengan berberapa pertimbangan:104 (1) ahli adalah professor di bidang kedokteran klinis pada School of Medicine, University of Southern California; (2) Ahli telah menyelesaikan studinya di bidang kedokteran di Yale University; (3) ahli telah menyelesaikan program selama tiga tahun tentang onkologi. ${ }^{105}$

Namun demikian, kriteria ini bukanlah satu-satunya cara bagi hakim untuk menilai bukti ilmiah. Kriteria ini paling tidak membantu hakim menyaring ahli yang tidak kompeten. ${ }^{106}$ Di dalam kasus Cano $v$. Everest Mineral Corp, walaupun hakim menerima ahli sebagai ahli yang kompeten dengan 3 (tiga)

102 Ibid.

103 Ibid. Berdasarkan hasil eksaminasi terhadap catatan medis dari korban serta penelitian independen, Dr. Malin Dollinger mengklaim bahwa ionisasi radiasi dari U-238 lebih mungkin menghasilkan pemecahan untai ganda (double-strand breaks) dalam DNA dengan kemampuan untuk memperbaiki (an impaired ability to repair). Ia menemukan bahwa dosis yang lebih tinggi mengarah ke risiko yang lebih tinggi secara proporsional.

104 Ibid.

105 Cancer Council of Australia, "What is Oncology?" https://www.cancer.org.au/healthprofessionals/oncology/, diakses 10 September 2018. Onkologi adalah sub-spesialisasi obat yang didedikasikan untuk penyelidikan, diagnosis, dan pengobatan penderita kanker atau kemungkinan kanker (suspected). Ini termasuk obat pencegahan, onkologi medis (kemoterapi, imunoterapi, terapi hormon, dan obat lain untuk mengobati kanker), onkologi radiasi (terapi radiasi untuk mengobati kanker), dan bedah onkologi (operasi untuk mengobati kanker).

106 Dominic J Nardi, Jr., "Do Indonesian Judges Need Scientific Credibility? Indonesia v. PT Newmont Minahasa Raya and the Use of Scientific Evidence in Indonesian Courts," Georgetown International Environmental Law Review, Vol. 21 issue 113, (2009), hlm. 137. 
pertimbangan diatas, namun tidak menjamin bahwa kesaksiannya adalah kesaksian yang kredibel (admissible). Salah satu keberatan yang disampaikan oleh pihak Tergugat adalah belum adanya konsensus dari metodologi yang digunakan oleh Dr. Malin Dollinger serta belum pernah dilakukan peer review. ${ }^{107}$ Hakim setuju dengan bantahan Tergugat dan juga menilai bahwa ahli tidak memperhatikan bukti lain yang bertentangan. ${ }^{108}$ Salah satunya adalah Laporan dari the U.N. Scientific Committee on the Effect of the Atomic Radiation yang menunjukan tingkat paparan yang berbeda dari berberapa jenis kanker yang disebabkan oleh Uranium. ${ }^{109}$

\section{B. Perkara Daubert v Merrell Dow Pharmaceuticals, Inc}

Selain merujuk pada Rule 702, hakim di Amerika Serikat juga seringkali merujuk pada putusan Mahkamah Agung ketika menangani perkara yang melibatkan bukti ilmiah dan pendapat ahli, termasuk dalam perkara lingkungan. Putusan tersebut adalah putusan perkara Daubert $v$ Merrell Dow Pharmaceuticals, Inc. ${ }^{110}$ (Putusan Daubert) yang memberikan kriteria yang lebih ketat dalam menilai suatu bukti ilmiah (dikenal sebagai kriteria Daubert).

Putusan Daubert memperjelas putusan dalam perkara Frye $v$ Amerika Serikat yang mengakui pendapat ahli sebagai bukti ilmiah yang didasarkan pada general acceptance rule. ${ }^{111}$ General acceptance rule, atau yang lebih dikenal sebagai 'Frye rule' menyatakan bahwa suatu pendapat ahli hanya dapat diterima (admissible) jika menggunakan teknik yang secara umum telah mendapat pengakuan dari suatu komunitas sains yang relevan sebagai teknik yang andal (reliable). Namun,

107 Cano v. Everest Mineral Corp., op. cit.

108 Ibid.

109 Ibid.

110 Supreme Court of The United States, Daubert v Merrell Dow Pharmaceuticals, Inc. (1993) 113 S. Ct 113 S. (1993).

111 D.C. Cir, Frye v United States 293F (1923), 1014. 
APLIKASI PRINSIP-PRINSIP TERKAIT BUKTI ILMIAH (SCIENTIFIC EVIDENCE) DI AMERIKA SERIKAT DALAM PEMBUKTIAN PERKARA PERDATA LINGKUNGAN DI INDONESIA

kesulitan seringkali timbul karena penanganan perkara lingkungan sering mengandalkan pada teori dan metodologi ilmiah yang baru. ${ }^{112}$ Hakim dalam perkara Daubert menolak general acceptance sebagai satu-satunya syarat diterimanya suatu bukti ilmiah dan menambahkan agar pendapat ahli yang dijadikan bukti ilmiah memenuhi kriteria sebagai berikut: ${ }^{113}$

1. Teori atau metode ilmiah yang digunakan telah teruji (falsifiability)

Untuk menentukan apakah suatu ilmu merupakan pengetahuan ilmiah (scientific knowledge) perlu dilakukan pengujian (to falsify) yang didasarkan pada observasi secara empiris. ${ }^{114}$ Contoh klasik failsifiability dapat dilihat dalam perkara Christophersen v. AlliedSignal Corp dimana penggugat mendalilkan bahwa bahan yang digunakan untuk membuat baterai nikel adalah penyebab penyakit kanker usus besar yang menyebabkan kematian. ${ }^{115}$ Ahli dari pihak penggugat memberikan kesaksian adanya kaitan antara hasil paparan terhadap nikel dan kadmium dengan sel karsinoma pada usus besar penderita. ${ }^{116}$ Kesaksian tersebut didasarkan pada beberapa studi yang dia yakini mengindikasikan adanya kaitan antara nikel dan kadmium dengan sel karsinoma di dalam paru-paru. Namun demikian pengadilan menolak kesaksian

${ }^{112}$ Steven M. Egesdal, The Frye Doctrine and Relevancy Approach Controversy: An Empirical Evaluation, Geo.L.J. Vol. 7 (1986), hlm. 1769.

113 Daubert v Merrell Dow Pharmaceuticals, op. cit.

${ }^{114}$ Karl R. Popper, The Logic of Scientific Discovery, edisi 2, 1968, hal 47, sebagaimana dikutip oleh Clifton T. Hutchinson dan Danny S. Ashby, “Daubert v. Merrell Dw Pharmaceutical, INC.: Redefining the Basis for Admissibility of expert Scientific Testimony", Cordozo Law Review, 15 (1993), hlm. 1888; lihat Brian J Preston, "Science and the Law: Evaluating Evidentiary Reliability" (tulisan disampaikan pada the Australian Conference of Planning and Environment Courts and Tribunals, Adelaide, 4-7 September 2002), hlm. 280-282. (1992).

$1155^{\text {th }}$ Cir. Christophersen v. Allied-Signal Corp, 939 F.2d 1106 (1991), cert. denied, 112 S. Ct. 1280 116 Ibid. 
tersebut. ${ }^{117}$ Pertimbangan hakim

didasarkan pada tidak adanya preseden di dalam epidemiologi kanker terkait kesimpulan ahli tersebut. ${ }^{118}$ Epidemiologi kanker adalah studi tentang distribusi dan determinasi dari kemungkinan perkembangan kanker. Epidemiologi kanker dapat digunakan untuk mengidentifikasi peristiwa yang meningkatkan atau menurunkan insiden kanker pada populasi tertentu. ${ }^{119}$ Tidak ada seorang pun ahli, termasuk ahli itu sendiri, yang telah mencoba untuk menyimpulkan (corroborate) hipotesa yang menyatakan kesamaan pathogenic dari kanker pada organ yang berbeda dapat diartikan bahwa kanker diakibatkan pada penyebab yang sama. ${ }^{120}$

2. Teori atau metode ilmiah memiliki unsur kesalahan (potential error rate) yang rendah dan didasarkan pada standar operasi yang benar (maintenance of operating standards)

Analisis potential error rate tidak digunakan untuk menilai suatu teori, melainkan digunakan dalam menilai prosedur sistematis untuk menghasilkan tahapan sains. ${ }^{121}$ Berbeda dengan falsifiability, yang mensyaratkan teknik yang dipakai adalah teknik yang valid, analisis potential error rate dilakukan untuk memastikan validitas dari teknik yang dipakai serta penerapan yang tepat dalam suatu kasus. ${ }^{122}$ Contoh penggunaan potential

117 Ibid.

118 Ibid.

119 nature.com, https://www.nature.com/subjects/cancer-epidemiology, diakses 10 September 2018.

120 Ibid., hlm. 1280.

121 Daubert $v$ Merrell Dow Pharmaceuticals, op. cit.

122 Clifton T. Hutchinson dan Danny S. Ashby, "Daubert v. Merrell Dw Pharmaceutical, INC.: Redefining the Basis for Admissibility of expert Scientific Testimony", Cordozo Law Review 15 (1993), 1896. 
error rate dapat dilihat dari tes jenis DNA seseorang. Setiap DNA manusia mempunyai keunikan tersendiri. Namun demikian, tidak semua teknik yang dipakai untuk mengetahui jenis DNA seseorang dapat mendeteksi keunikan tersebut dengan tingkat akurasi yang tinggi. ${ }^{123}$ Suatu teknik misalnya sudah dibuktikan dengan dasar teori yang valid. Namun demikian apabila teknik ini tidak didukung oleh peralatan yang beroperasi secara baik, teknisi yang berkualitas dalam pengoperasian, pengoperasian dengan prosedur yang benar, maka akan dapat menghasilkan hasil yang tidak akurat.124 Terkait dengan kondisi tersebut, validitas suatu standar operasi tidak hanya ditentukan apakah ahli telah mengunakan teknik yang valid, tetapi juga apakah ahli tersebut mengoperasikan teknik tersebut secara benar. ${ }^{125}$

3. Teori atau teknik yang digunakan telah direview (peer review) dan dipublikasikan. ${ }^{126}$ Peer review adalah metode yang sudah terinstitusionalisasi untuk mereview masuk akalnya (plausibility) suatu output yang bersifat sains serta tingkat ketepatan (correctness) dari suatu metodologi dan analisis yang digunakan untuk menghasilkan output tersebut. ${ }^{127}$ Proses peer review yang ketat menentukan sejauh mana suatu klaim tentang suatu pengetahun dianggap sebagai suatu sains. ${ }^{128}$ Menurut hakim dalam perkara Daubert,

123 Ibid.

124 Paul C. Giannelli, The Admissibility of Novel Scientific Evidence: Frye v. United States, a half century later, 80 COLUM. L.REV. 1197, 1201 (1980) sebagaimana dikutip oleh Clifton T. Hutchinson dan Danny S. Ashby, op. cit.

${ }^{125}$ Lihat $11^{\text {th }}$ Cir, United States v. Else, 743 F.2d 1465, 1474 (1984) sebagaimana dikutip oleh Clifton T. Hutchinson dan Danny S. Ashby, op. cit.

126 Sejauh mana suatu klaim ilmiah dapat dikatakan sebagai 'good science' akan tergantung pada sejauh mana klaim tersebut telah melewati proses 'peer review' dan publikasi yang berkualitas dari komunitas ilmiah yang relevan.

127 Clifton T. Hutchinson dan Danny S. Ashby, op. cit., 1900.

128 Ibid. 
proses yang ketat tersebut akan mendeteksi secara seksama adanya kesalahan subtantif (substantive flaws) atas metodologi yang dipakai. ${ }^{129}$ Namun demikian, hakim dalam perkara Daubert menyatakan peer review bukan sebagai penilaian yang sifatnya mutlak. ${ }^{130}$ Misalnya, klaim tentang sains yang masih sangat baru (novel) tidak secara otomatis dapat dianggap tidak melewati proses peer review yang cukup. ${ }^{131}$ Klaim tersebut perlu ditimbang dengan standar validasi yang lain sebelum dapat dikecualikan sebagai suatu bukti. ${ }^{132}$ penerimaan bukti ilmiah di pengadilan Amerika Serikat. Hakim tidak lagi hanya mengunakan proses penilaian berdasarkan general acceptance rules sebagaimana yang ditentukan dalam perkara Frye. Sejak perkara Daubert, hakim perlu melakukan penilaian terhadap setiap bukti ilmiah, pendapat ahli serta bukti-bukti lain yang relevan. Beberapa orang berpendapat bahwa Kriteria Daubert akan mendorong proses pembuktian dan penggunaan bukti ilmiah di pengadilan secara lebih ketat. ${ }^{133}$ Namun demikian, ada juga yang meragukan kemampuan hakim untuk membuat putusan yang tepat terkait dengan sains, mengingat Kriteria Daubert membutuhkan pemahaman tentang sains yang

\section{Catatan Kritis Terhadap Kriteria \\ Daubert}

Putusan Daubert secara prinsip telah mengubah panduan proses

\footnotetext{
129 Daubert v Merrell Dow Pharmaceuticals, Inc, op. cit. 2797.

130 Ibid.

131 Ibid.

132 Ibid.

133 David E Bernstein, "The Admissibility of Scientific Evidence after Daubert v. Merrell Dow
} Pharmaceuticals, Inc." Cardozo Law Review 15, (1993), hlm. 2139. 
mumpuni. ${ }^{134}$ Dengan menerapkan

Kriteria Daubert secara ketat, pengadilan mungkin saja tidak sadar telah mengenyampingkan suatu bukti ilmiah yang secara keseluruhan sebenarnya dapat mendukung argumentasi ilmiah. ${ }^{135}$ Untuk mencegah hal ini terjadi, hakim harus melakukan penilaian secara keseluruhan terhadap semua bukti ilmiah (terintegrasi). Namun, ini merupakan beban yang sangat berat buat hakim karena mensyaratkan hakim memiliki kemampuan layaknya seorang ilmuwan. ${ }^{136}$

\section{Pendayagunaan Bukti Ilmiah dalam Perkara Lingkungan Perdata di Indonesia}

Persyaratan diterimanya pendapat ahli sebagai bukti ilmiah sebagaimana diterapkan di Amerika Serikat dapat menjadi referensi yang menarik bagi
Indonesia. Tulisan ini mengidentifikasi setidaknya ada dua aspek penting dalam membahas bukti ilmiah dan kesaksian ahli yang relevan dengan Indonesia. Pertama, keberadaan metode ilmiah yang valid. Artinya, bukti ilmiah harus diperoleh berdasarkan metode sains. ${ }^{137}$ Kedua, aspek pengetahuan khusus. Aspek ini memastikan bahwa opini yang disampaikan didasarkan oleh keahlian yang dimiliki. Artinya, setelah suatu opini atau bukti ilmiah diterima sebagai suatu pengetahuan ilmiah (scientific knowledge), tahapan selanjutnya adalah memastikan apakah pendapat ahli tersebut didasarkan pada keahlian yang diperoleh berdasarkan pendidikan, pelatihan dan pengalaman di bidang yang terkait dengan masalah yang dibahas dalam kasus. ${ }^{138}$

Selanjutnya, tulisan ini akan membahas sejauh mana hukum di

134 Carl F Cranor, "A Framework for Assessing Scientific Arguments: Gaps, Relevance and Integrated Evidence," Journal of Law \& Policy, Brooklyn Law School Vol. 15 (7) (2007), hlm. 8.

135 Dominic J Nardi, Jr., op. cit., hlm. 119.

${ }^{136}$ Carl F Cranor, op. cit., hlm. 25. Misalnya, dalam suatu peristiwa paparan bahan kimia beracun, hakim mungkin menghadapi kesulitan dalam menilai kesimpulan ahli tentang kadar kontaminasi produk yang dikumpulkan dari 'berbagai jenis bukti yang relevan dan sufisien'.

137 Daubert v Merrell Dow Pharmaceuticals, Inc. op. cit.

138 Wawancara dengan Justice Brian J. Preston, Ketua Pengadilan Land \& Environment Court, New South Wales, Australia. 
Indonesia mengatur bukti ilmiah serta implementasinya dalam penanganan perkara di pengadilan melalui pendekatan doktrinal. Tulisan ini dengan sengaja membatasi peraturan yang dikaji, yakni Kitab UndangUndang Hukum Acara Perdata dan Surat Keputusan Ketua Mahkamah Agung No. 36/KMA/SK/II/2013 tentang Pemberlakuan Pedoman Penanganan Perkara Lingkungan Hidup. ${ }^{139}$ Untuk membantu menganalisis, akan digunakan satu studi kasus, yaitu putusan perkara kebakaran hutan yang terdiri dari Putusan Pengadilan Negeri Jakarta Utara No. 108/Pdt.G/2015/PN.Jkt.Utr. dalam perkara Menteri Lingkungan Hidup dan Kehutanan Republik Indonesia v. PT. Jatim Jaya Perkasa serta Putusan Pengadilan Tinggi. DKI No. 727/PDT/2016/PT.DKI dalam perkara antara Menteri Lingkungan Hidup dan Kehutanan Republik Indonesia v. PT. Jatim Jaya Perkasa. ${ }^{140}$

\section{A. Peraturan tentang Bukti Ilmiah di Indonesia}

Pembuktian hukum perdata didasarkan pada suatu prinsip bahwa barang siapa mempunyai sesuatu hak atau, guna membantah hak orang lain, menunjuk pada suatu peristiwa, diwajibkan membuktikan adanya hak atau peristiwa tersebut. ${ }^{141}$ Berdasarkan prinsip ini, dalam persidangan hakim akan memberikan beban pembuktian kepada para pihak untuk membuktikan dalil-dalil yang disampaikan. Terhadap alat-alat bukti yang disampaikan tersebut, hakim selanjutnya melakukan penilaian sejauh mana kekuatan alat bukti tersebut berdasarkan ketentuan yang

\footnotetext{
139 Indonesia, Mahkamah Agung, op. cit.

${ }^{140}$ Ketika tulisan ini dibuat, Mahkamah Agung pada tanggal 28 Juni 2018 menolak permohonan kasasi yang diajukan oleh JJP. Putusan kasasi menguatkan putusan yang dibuat oleh Pengadilan Tinggi DKI. https://www.badungkab.go.id/instansi/dislhk/baca-berita/2047/Angin-Segar-PenegakanHukum-Karhutla-dari-MA.html. Tulisan ini tidak memasukan pertimbangan putusan Mahkamah Agung dalam melakukan analisis dikarenakan dokumen putusan belum dapat diakses di Mahkamah Agung.

${ }^{141}$ Kitab Undang-Undang Hukum Acara Perdata [Het Herzein Inlandsch Reglement/Reglemen Indonesia yang Diperbaharui], diterjemahkan oleh Tim Visi Yustisia, (Jakarta, Visi Media Pustaka, 2015), ps 1865.
} 
APLIKASI PRINSIP-PRINSIP TERKAIT BUKTI ILMIAH (SCIENTIFIC EVIDENCE) DI AMERIKA SERIKAT DALAM PEMBUKTIAN PERKARA PERDATA LINGKUNGAN DI INDONESIA

berlaku. ${ }^{142}$ Berbeda dengan hukum pembuktian pidana yang mencari kebenaran material, ${ }^{143}$ dalam pembuktian hukum perdata hakim mencari kebenaran formil. Hal ini berarti bahwa kekuatan alat bukti yang sah menurut hukum bersifat 'mengikat' hakim dalam pengambilan keputusan.

KUHPerdata mengenal berberapa jenis alat bukti, yaitu: alat bukti tertulis, kesaksian, persangkaan, pengakuan, dan sumpah. ${ }^{144}$ Sementara itu Pasal 154 HIR menentukan bahwa keterangan ahli dapat digunakan apabila diperlukan. Pendapat ahli berfungsi untuk menambah keyakinan hakim dan sifatnya tidak dapat berdiri sendiri. Namun demikian, bukti ilmiah tidak disebutkan secara khusus dalam jenisjenis alat bukti dalam hukum tersebut.
Surat Keputusan Ketua Mahkamah Agung No. 36/KMA/SK/II/2013 tentang Pemberlakuan Pedoman Penanganan Perkara Lingkungan Hidup menentukan bahwa bukti ilmiah dapat digunakan dalam perkara lingkungan. Tujuan bukti ilmiah dalam kasus lingkungan adalah untuk menambah keyakinan hakim serta memberikan panduan bagi hakim untuk menilai keotentikan suatu alat bukti. ${ }^{145}$ Pedoman tersebut memberikan contoh-contoh bukti ilmiah, antara lain hasil analisis laboratorium, penghitungan ganti rugi akibat pencemaran dan/atau kerusakan yang disampaikan oleh ahli. ${ }^{146}$ Pedoman juga menyatakan bahwa untuk dapat menjadi bukti hukum, bukti ilmiah tersebut harus didukung dengan keterangan ahli di persidangan. ${ }^{147}$ Berdasarkan ketentuan

\footnotetext{
${ }_{142}$ Achmad Ali dan Wiwie Heryani, Asas-Asas Hukum Pembuktian Perdata, edisi 1, (Jakarta: Kencana Perdana Media Group, 2012), hlm. 51.

${ }^{143}$ Indonesia. Undang-Undang Hukum Acara Pidana. UU No. 8 Tahun 1981. LN No. 76 Tahun 1981, TLN No. 3258, ps 183 "seseorang hanya dapat dihukum apabila hakim berdasarkan alat bukti yang sah memperoleh keyakinan bahwa suatu tindak pidana telah terjadi serta terdakwa tersebut telah bersalah melakukannya."

${ }^{144}$ Kitab Undang-Undang Hukum Acara, op. cit. Ps 1866.

145 Indonesia, Mahkamah Agung, op. cit. hlm. 23.

146 Ibid.

147 Ibid.
} 
tersebut, hakim menilai bukti-bukti yang dihadirkan oleh para pihak secara keseluruhan. Artinya, Hakim menentukan validitas dengan melihat kesesuaian suatu bukti dengan bukti lain dalam rangka menemukan peristiwa hukum serta membuat kesimpulan. ${ }^{148}$

Lebih lanjut Pedoman tersebut mengatur apabila hakim dihadapkan pada beberapa pendapat ahli yang bertentangan, hakim berdasarkan keyakinannya memilih keterangan (yang paling kredibel) ${ }^{149}$ dengan memberikan pertimbangan alasan dipilihnya keterangan alat bukti yang disampaikan oleh ahli tersebut. ${ }^{150}$ Hakim juga dapat menunjuk ahli lain atau menerapkan prinsip kehatihatian. ${ }^{151}$ Terkait dengan penanganan kasus lingkungan yang banyak melibatkan bukti ilmiah, Pedoman ini sudah banyak digunakan dan membantu dalam pembuktian yang melibatkan bukti ilmiah dan keterangan ahli. ${ }^{152}$

Pedoman ini juga memberikan kriteria khusus yang harus dimiliki oleh seorang ahli untuk dapat bersaksi di pengadilan dalam kasus lingkungan. Kriteria tersebut meliputi: (1) memiliki disiplin ilmu sesuai dengan perkara yang dibuktikan melalui ijazah, minimal S2 (akademis) atau mendapat pengakuan masyarakat sebagai ahli; (2) pernah menyusun atau membuat karya ilmiah atau penelitian relevan (pakar); (3) aktif dalam seminar atau lokakarya dan tercantum daftar riwayat hidup $(\mathrm{CV}) .153$

Peraturan yang berlaku saat ini terlihat sudah mengakomodir

148 Putusan Kalista Alam (2015) menjadi 'standar' yang dipakai oleh putusan pengadilan selanjutnya dalam membuktikan adanya kebakaran hutan dengan penilaian secara keseluruhan dari bukti ilmiah yang disampaikan penggugat yang terdiri dari data hotspot berdasarkan rekaman citra satelit, hasil verifikasi lapangan serta hasil analisis data di laboratorium.

149 Tambahan dari penulis.

150 Indonesia, Mahkamah Agung, op. cit., hlm. 23.

151 Ibid.

152 Pedoman memberikan contoh-contoh dari bukti ilmiah seperti analisa hasil laboratorium, data hotspot serta interpretasinya. Untuk dapat menjadi bukiti hukum, bukti ilmiah harus didukung dengan keterangan ahli di persidangan. Surat/dokumen pendukung pengambilan contoh harus dilakukan oleh orang/organisasi yang kredibel dan terakreditasi serta dibuat berita acara secara rinci.

153 Indonesia, Mahkamah Agung, op. cit., hlm. 48. 
pendapat ahli dan bukti ilmiah dalam proses pembuktian di pengadilan. Namun, masih ada beberapa hal yang perlu dipertegas, antara lain tentang prosedur penilaian suatu bukti ilmiah atau keterangan ahli sebagai bukti yang relevan, prosedur untuk menentukan validitas bukti ilmiah dan penentuan kriteria pengetahuan khusus bagi ahli. Artinya, pedoman tidak secara khusus memberikan pedoman untuk menentukan suatu bukti ilmiah sebagai sesuatu yang bersifat sains, diperoleh melalui metode yang valid yang sudah mendapatkan pengakuan dari komunitas sains yang relevan. Terkait dengan kriteria ahli, prasyarat yang ditentukan masih bersifat umum yang tidak memberikan pedoman kepada hakim untuk memastikan bahwa pendapat ahli didasarkan pada keahlian khusus yang terkait.

\section{B. Bukti Ilmiah dalam Proses Pembuktian Perkara Jatim Jaya Perkasa}

Kebakaran hutan merupakan permasalahan yang terjadi hampir setiap tahun di Indonesia. Kebakaran hutan terbesar terjadi pada pada kurun waktu 1997-1998. Sejak saat itu, hampir setiap tahun berturut-turut, terjadi kebakaran hutan di berbagai wilayah. Badan Nasional Penanggulangan Bencana (BPNB) memperkirakan bahwa kerugian negara yang ditimbulkan dari kebakaran hutan antara tahun 1997-2015 mencapai 221 triliun rupiah. ${ }^{154}$

Banyak terdapat perkara kebakaran hutan yang memiliki dimensi bukti ilmiah. Salah satu perkara kebakaran hutan yang memiliki dimensi sains adalah putusan perkara P.T. Jatim Jaya Perkasa (JJP). Alasan dipilihnya perkara JJP karena perkara ini memiliki perdebatan penting terkait dengan aspek keberadaan metodologi yang andal

${ }^{154}$ Ann Jeannette Glaubber, dkk, “Kerugian dari Kebakaran Hutan: Analisa Dampak Ekonomi dari Krisis Kebakaran Tahun 2015", Laporan Pengetahuan lanskap Berkelanjutan Indonesia No.1 World Bank Group, 2016, hlm. 1. 
serta aspek pengetahuan khusus terkait bukti ilmiah. Hal tersebut dapat dilihat dari perbedaan pertimbangan hakim pengadilan negeri dan pengadilan tinggi terkait bukti ilmiah dalam perkara tersebut. Pembahasan perbedaan tersebut dalam kerangka akademis dapat menjadi pelajaran dan masukan yang penting khususnya bagi penguatan hakim.

Perkara ini dimulai pada tahun 2013, ketika Kementerian Lingkungan Hidup dan Kehutanan (KLHK) mengajukan gugatan kepada PT. JJP ke Pengadilan Negeri (PN) Rokan Hilir, Riau. Dalam gugatannya, KLHK mendalilkan bahwa perusahaan tersebut telah lalai dalam melakukan pembukaan lahan, sehingga menyebabkan terbakarnya lahan gambut seluas 1000 ha di wilayahnya. 155 Akibat dari kelalaian tersebut, Penggugat memperkirakan negara menderita sebesar Rp. 491.025.500.000,00 156
PN Rokan Hilir mengabulkan gugatan KLHK sebagian dengan menyatakan bahwa P.T. JJP bertanggung jawab terhadap terjadinya kebakaran. ${ }^{157}$ Namun, PN tidak sepakat dengan penggugat terkait total luas wilayah yang terbakar. ${ }^{158}$ Menurut PN, total luas kawasan yang terbakar hanyalah 120 ha, jauh lebih kecil dari perhitungan Penggugat. Akibatnya, PN menentukan nilai ganti kerugian yang jauh lebih kecil dari tuntutan Penggugat, yakni kerugian materiel sebesar Rp. 7.196.188.475,00. Di samping itu PN juga mengharuskan P.T. JJP melakukan tindakan pemulihan lingkungan terhadap lahan yang terbakar dengan nilai sebesar Rp. 22.277.130.853,00.159

Atas putusan PN tersebut, KLHK mengajukan banding ke Pengadilan Tinggi (PT) Riau. Dalam putusannya, Majelis Hakim PT menguatkan putusan PN dan menyatakan bahwa telah terjadi kebakaran di wilayah kerja

\footnotetext{
155 Pengadilan Negeri Jakarta Utara, Putusan No. 108/Pdt.G/2015/PN.Jkt.Utr., op. cit. hlm. 15.

156 Ibid., hlm. 38.

157 Ibid., hlm. 166.

158 Ibid., hlm. 167.

159 Ibid., hlm. 170.
} 
APLIKASI PRINSIP-PRINSIP TERKAIT BUKTI ILMIAH (SCIENTIFIC EVIDENCE) DI AMERIKA SERIKAT DALAM PEMBUKTIAN PERKARA PERDATA LINGKUNGAN DI INDONESIA

P.T. JJP. Namun, Majelis Hakim PT menolak pertimbangan Majelis Hakim PN terkait dengan luas wilayah kebakaran. Majelis Hakim PT menentukan bahwa luas wilayah yang terbakar jauh di atas perhitungan Majelis Hakim PN, yakni 1000 ha. ${ }^{160}$ Sebagai konsekuensi, Majelis Hakim PT menghukum Tergugat untuk membayar kerugian materiel yang juga sangat besar, yakni Rp. 119.888.500.000,00 serta melakukan tindakan pemulihan lingkungan terhadap lahan yang terbakar dengan nilai sebesar Rp. 371.137.000.000,00.161

Tulisan ini berpendapat bahwa terdapat 3 (tiga) hal terkait bukti ilmiah yang saling bertentangan yang diajukan oleh para pihak dalam perkara PT. JJP ini, yang pada gilirannya mempengaruhi putusan hakim. Pertentangan pertama, terkait lokasi terjadinya kebakaran lahan. Kedua, luas wilayah yang terbakar. Ketiga, besarnya nilai kerugian lingkungan dan biaya pemulihan yang diperlukan.

\section{Lokasi Terjadinya Kebakaran}

Terkait dengan lokasi terjadinya kebakaran, Ahli dari pihak Penggugat memberikan bukti data hotspot yang diperoleh dari satelit MODIS pada periode bulan Juni 2013. Berdasarkan data tersebut, peristiwa kebakaran lahan terindikasi terjadi sejak awal Juni 2013 di berbagai titik yang berbeda. ${ }^{162}$ Untuk memastikan bahwa titik hotspot tersebut adalah titik api kebakaran, Penggugat melakukan verifikasi lapangan yang dilakukan oleh tim yang ditunjuk oleh KLHK, yang beranggotakan para ahli dan staf pada tanggal 6 November 2013. ${ }^{163}$ Sementara

160 Pengadilan Tinggi Jakarta, Putusan No. 727/PDT/2016/PT.DKI, op. cit. hlm. 79.

161 Ibid., hlm. 81.

162 Untuk memberikan keyakinan awal apakah benar terjadi kebakaran pada titik-titik hotspot tersebut telah dilakukan pemeriksaan melalui aplikasi Google Earth dengan mengecek citra yang terekam oleh satelit pada lokasi-lokasi yang terindikasi adanya titik panas - menunjukan bahwa hotspot yang terindikasi di titik koordinat yang terbukti masuk wilayah usaha perkebunan.

163 Pengadilan Negeri Jakarta Utara, Putusan No. 108/Pdt.G/2015/PN.Jkt.Utr., op. cit., hlm. 9. (1) Titik koordinat lokasi lahan bekas kebakaran benar terjadi di wilayah PT. JJP; (2) Telah terjadi kebakaran di areal HGU Tergugat khususnya pada lahan inti pada areal kosong tanpa tanaman dan pada areal yang telah ditanami sawit tapi dengan kualitas yang sangat tidak baik; (3) memastikan bahwa 
itu, Tergugat berpendapat perlu dilakukan proses rekognisi dan proses verifikasi secara real time untuk memastikan bahwa sebuah hotspot adalah benar-benar titik api (firespot). ${ }^{164}$ Tergugat menyatakan bahwa verifikasi lapangan yang dilakukan oleh Penggugat pada tanggal 6 November 2013 tersebut bukan merupakan verifikasi yang dilakukan secara real time. ${ }^{165}$

Majelis Hakim juga menerima pendapat Ahli pihak Tergugat yang menyatakan bahwa cuaca yang sangat ekstrim pada periode Mei hingga Juni 2013 berkontribusi pada terjadinya kebakaran. ${ }^{166}$ Kondisi ini menyebabkan adanya temperatur yang sangat tinggi yang dapat memindahkan materiel yang terbakar yang berasal dari tanah masyarakat. ${ }^{167}$ Ditambah dengan keterangan saksi masyarakat soal api yang bersumber dari lahan masyarakat, Majelis Hakim menerima eksepsi Tergugat (berdasarkan pendapat para Ahli) tentang sumber api yang bukan berasal dari kegiatan Tergugat. 168

\section{Luas Wilayah yang Terbakar}

Terkait dengan luas wilayah yang terbakar, ahli dari pihak Penggugat menentukan luas wilayah yang terbakar berdasarkan verifikasi secara fisik dengan menggunakan metode sampling. ${ }^{169}$ Contoh diambil di 5 (lima) blok lokasi kebakaran dalam wilayah Tergugat. Salah satu contoh diambil dari lahan yang tidak terbakar, sebagai data kontrol untuk membandingkan kondisi kandungan tanah yang terbakar dengan kondisi tanah yang tidak terbakar. ${ }^{170}$ Berdasarkan metode tersebut, ahli dari pihak Penggugat menyimpulkan bahwa luas wilayah

kebakaran terjadi bukan tanpa alasan tetapi merupakan bagian dari upaya melakukan penyiapan lahan dengan pembakaran melalui pembiaran; (4) tidak tersedianya sarana dan prasarana pengendalian kebakaran hutan di seputar areal yang terbakar; (5) lahan bekas terbakar merupakan lahan gambut; dan (6) Ditemuinya berberapa tanda-tanda fisik bekas kebakaran hutan.

164 Pengadilan Negeri Jakarta Utara, Putusan No. 108/Pdt.G/2015/PN.Jkt.Utr., op. cit., hlm. 47.

165 Ibid., hlm. 48.

166 Ibid, hlm. 138 - 139.

167 Ibid, hlm. 139.

168 Ibid, hlm. 157.

169 Ibid, hlm. 15.

170 Ibid, hlm. 16. 
APLIKASI PRINSIP-PRINSIP TERKAIT BUKTI ILMIAH (SCIENTIFIC EVIDENCE) DI AMERIKA SERIKAT DALAM PEMBUKTIAN PERKARA PERDATA LINGKUNGAN DI INDONESIA

yang terbakar adalah 1.000 ha. ${ }^{171}$

Tergugat menolak hasil perhitungan tersebut dan menyatakan bahwa perhitungan tersebut hanya berdasarkan asumsi dan tidak valid. Luas yang terbakar menurut Tergugat hanya seluas 113,9 ha. ${ }^{172}$ Tergugat mendasarkan luas tersebut pada pengakuan Penggugat atas wilayah yang terbakar pada saat kunjungan lapangan. ${ }^{173}$ Tergugat mempertanyakan tentang metode sampling yang dilakukan. Walaupun hanya dilakukan terhadap lima lokasi blok yang terbakar, tetapi dijadikan dasar kesimpulan oleh ahli Penggugat untuk menentukan jumlah keseluruhan areal yang terbakar sebesar 1000 ha. ${ }^{174}$ Majelis Hakim PN menerima eksepsi yang disampaikan Tergugat tersebut dengan dasar bukti luas wilayah terbakar dan saksi-saksi yang disampaikan Tergugat. ${ }^{175}$

Namun, Majelis Hakim PT menolak pertimbangan tersebut. Hakim menerima perhitungan dengan menggunakan metode sampling yang diajukan oleh ahli dari pihak Penggugat dalam menentukan luas wilayah kebakaran hutan. Selain itu, Majelis Hakim juga mengakui metode untuk menentukan titik hotspot yang dijadikan dasar penghitungan, dengan alasan bahwa metode tersebut sudah diakui secara ilmiah. Kaidah hukum yang mendasari pertimbangan hakim adalah bahwa pembuktian dalam kerusakan lingkungan tidak hanya menggunakan keterangan saksi-saksi, tapi yang paling penting adalah pembuktian ilmiah, verifikasi di lapangan dan analisa di

171 Ibid, hlm. 16.

172 Ibid, hlm. 59

$173 \mathrm{Ibid}$, hlm. 57. Penggugat menyatakan bahwa wilayah yang terbakar terletak pada Blok S3 D-E, Blok S4, S5, S6, S7, S8 dan S9 A, B, C, D dan E, Blok T4, T5, T6, T7, T8 dan T9.

174 Ibid, hlm. 57.

$175 \mathrm{Ibid}$, hlm. 166. 'Menimbang bahwa berdasarkan bukti P-28 bahwa lahan Tergugat yang terbakar adalah pada sebagian blok $\mathrm{S}$ dan $\mathrm{T}$ seluas $120 \mathrm{Ha}$, dan dari bukti P-28 tersebut yang apabila dihubungkan dengan keterangan saksi Handa Saputra dan Tukiman bahwa hanya sebagian lahan di blok S dan T yang terbakar, maka dengan demikian Majelis Hakim menetapkan bahwa lahan Tergugat yang terbakar adalah seluas 120 ha...' 
labolatorium. ${ }^{176}$

\section{Besarnya Nilai Kerugian yang Ditimbulkan Serta Biaya}

\section{Pemulihan Lingkungan}

Penggugat mendasarkan

penghitungan ganti kerugian serta biaya pemulihan akibat kebakaran lahan berdasarkan Peraturan Menteri Lingkungan No. 7 Tahun 2014 tentang Ganti Kerugian Akibat Pencemaran dan Kerusakan Lingkungan. ${ }^{177}$ Menurut Penggugat, kebakaran lahan yang terjadi di wilayah Tergugat mengakibatkan kerugian lingkungan, yang terdiri dari kerugian ekologis ${ }^{178}$ serta kerugian ekonomis berupa hilangnya umur pakai. Sedangkan biaya pemulihan yang diajukan penggugat terdiri dari: biaya pemulihan lahan gambut bekas terbakar, biaya pembelian kompos, biaya angkut, biaya penyebaran kompos, dan biaya pemulihan untuk mengaktifkan fungsi ekologis.

Tergugat menolak perhitungan serta nilai yang ditentukan tersebut. ${ }^{179}$ Majelis Hakim PN menerima metode penghitungan yang disampaikan oleh Penggugat, namun sebagaimana telah disampaikan sebelumnya, Majelis Hakim tidak sepakat dengan luas wilayah yang terbakar. Berdasarkan hal tersebut, Majelis Hakim PN hanya mengabulkan ganti rugi dan pemulihan sesuai dengan luas wilayah terbakar, yakni 120 ha. ${ }^{180}$

176 Ibid., hlm. 78.

177 Dari uraian tersebut, total kerugian lingkungan adalah sebesar Rp. 119.885.500.000 dan total biaya pemulihan adalah Rp. 371.137.000.000.

178 Terdiri dari biaya pembuatan reservoir, biaya pemeliharaan reservoir, pengaturan tata air, pengendalian erosi, pembentuk tanah, pendaur ulang unsur hara, pengurai limbah, dan kerugian atas hilangnya keanekaragaman hayati dan sumberdaya genetika, kerugian akibat terlepasnya Karbon ke udara (terdiri dari lepasnya Karbon dan hilangnya perosot Karbon/Carbon Reduction).

179 Salah satunya adalah tidak dilakukannya pemeriksaan dalam waktu yang cepat (real time) atas terlepasnya gas rumah kaca.

180 Pengadilan Negeri Jakarta Utara, Putusan No. 108/Pdt.G/2015/PN.Jkt.Utr., op. cit., hlm. 167. Hakim berpendapat karena tidak ada peraturan yang menetapkan besara ganti rugi, selain melalui penghitungan ahli, maka majelis hakim dapat menerima besaran ganti rugi sebagaimana disebutkan Penggugat dalam gugatannya. Hal lain yang menjadi pertimbangan hakim terkait besarnya ganti kerugian adalah: (1) hutan tidak rusak rempurna dan masih dapat ditanah kembali; (2) kebakaran bukan berasal dari lahan Tergugat melainkan dari lahan masyarakat yang merembet ke lahan Tergugat; 
Berbeda dengan putusan PN, Majelis Hakim PT mengabulkan seluruh nilai ganti kerugian dan biaya pemulihan yang diajukan oleh Penggugat. Putusan Majelis Hakim tersebut didasarkan pada pertimbangan bahwa kebakaran terjadi di wilayah yang sangat luas, yaitu 1000 ha. Di samping itu Majelis Hakim PT juga mempertimbangkan bahwa kebakaran lahan tersebut telah mengakibatkan kerusakan lingkungan hidup yang dampaknya berpotensi tidak dapat dipulihkan lagi. ${ }^{181}$

\section{Federal Rule of Evidence 702, Kriteria Daubert dan Pendayagunaan Bukti Ilmiah di Indonesia}

Sebagaimana disampaikan sebelumnya, penggunaan bukti ilmiah di Amerika Serikat didasarkan pada Federal Rules of Evidence, Rule 702 dan Kriteria Daubert. Tulisan ini melihat bahwa aturan dan kriteria tersebut sangat ketat dan rinci, sehingga dapat membantu hakim dalam menilai bukti ilmiah dalam proses pembuktian di pengadilan. Apabila aturan dan kriteria tersebut digunakan untuk menganalisis pendayagunaan bukti ilmiah dalam penanganan perkara di pengadilan di Indonesia, maka diharapkan dapat membantu mengidentifikasi kekurangan yang ada.

\section{A. Keberadaan Metodologi Sains yang Andal}

Kriteria Daubert mensyaratkan agar teori dan metode yang digunakan dalam menentukan bukti ilmiah telah teruji secara ilmiah (falsifiability test), potential error rate-nya rendah, telah melalui peer review dan telah diterima oleh komunitas ilmiah (general acceptance). Jika menggunakan kriteria tersebut, terlihat bahwa Pedoman Penanganan Perkara Lingkungan Hidup yang dikeluarkan Mahkamah Agung belum memberikan arahan bagaimana menilai suatu bukti ilmiah

(3) dengan kedua hal tersebut majelis hakim menganggap adil apabila dibebankan kepada Tergugat separo (1/2) dari nilai kerugian yang timbul di lahan Tergugat.

181 Pengadilan Tinggi Jakarta, Putusan No. 727/PDT/2016/PT.DKI, op. cit. hlm. 79. 
atau bagaimana memastikan keterangan ahli didasarkan pada teori atau metode ilmiah. Pedoman hanya memberikan acuan yang perlu dilakukan oleh hakim bila terjadi perbedaan antara bukti ilmiah dan keterangan ahli.

Terkait dengan data hotspot, walaupun hakim menerima telah terjadinya kebakaran di lahan Tergugat, Majelis Hakim PN tidak memberikan pertimbangan secara khusus tentang validitas bukti hotspot yang disampaikan oleh Penggugat terkait verifikasi secara real time. Hal ini penting untuk dilakukan untuk memastikan validitas bukti ilmiah. khususnya apakah metode yang dilakukan dalam menentukan titik koordinat kebakaran telah dilakukan dengan metode yang valid dan pelaksanaan dilakukan dengan cara yang benar. Dalam kriteria Daubert, proses ini terkait dengan pengujian standar operasi yang benar (maintenance of operating standards).
Sementara itu, Majelis Hakim PT tampaknya telah menggunakan salah satu Kriteria Daubert, yakni prinsip general acceptance. Di sini, Majelis Hakim PT menilai apakah bukti ilmiah didasarkan atas suatu metode yang valid. Misalnya, Majelis menilai data hotspot dihasilkan oleh foto citra satelit yang dianggap sudah diakui secara ilmiah dan data tersebut telah diverifikasi dan dianalisis di laboratorium oleh ahli kebakaran hutan. ${ }^{182}$ Namun demikian, Majelis belum secara rinci menilai keberadaan metode yang valid dalam menentukan penyebab serta dampak terjadinya kebakaran.

Terkait dengan penyebab kebakaran, Majelis Hakim PN belum membandingkan keterangan ahli Penggugat yang menjelaskan bukti hotspot, hasil verifikasi lapangan, dan analisis laboratorium dengan pendapat ahli Tergugat tentang pengaruh cuaca terhadap pemicu kebakaran di wilayah Tergugat. Majelis tidak menilai apakah teori atau metode yang mendasari

182 Ibid. 
APLIKASI PRINSIP-PRINSIP TERKAIT BUKTI ILMIAH (SCIENTIFIC EVIDENCE) DI AMERIKA SERIKAT DALAM PEMBUKTIAN PERKARA PERDATA LINGKUNGAN DI INDONESIA

pendapat ahli Tergugat adalah valid. Selain itu, Majelis Hakim PN tidak secara khusus menilai terkait metodologi. Hakim tidak menilai apakah metode sampling tepat digunakan untuk menentukan luas seluruh wilayah yang terbakar. Dari pertimbangan Majelis Hakim PN diatas dapat dilihat bahwa Majelis Hakim PN lebih memberikan bobot yang lebih berat kepada bukti selain bukti ilmiah dalam membuktikan pencemaran/perusakan lingkungan. Hal ini dapat menunjukan adanya kebutuhan pemahaman ilmiah yang memadai bagi hakim.

Sementara itu, terkait dengan dampak kebakaran, ahli-ahli dari Penggugat menyatakan bahwa ketebalan gambut yang terbakar bervariasi sampai kedalaman $75 \mathrm{~cm}$, sedangkan ahli-ahli dari pihak Tergugat menyampaikan ketebalan gambut yang terbakar hanya sampai kedalaman $15 \mathrm{~cm} .{ }^{183}$ Majelis Hakim PN mengakui hal ini disebabkan oleh tidak samanya pengambilan titik sampel.
Namun demikian, pertimbangan tersebut tidak disertai dengan pemeriksaan secara rinci apakah sampel tersebut adalah sampel yang relevan dengan kebakaran. Validitas dari sampel tersebut akan menentukan apakah pendapat Ahli adalah pendapat yang kredibel. Terdapat kaitan yang sangat erat antara opini, metodologi serta data yang digunakan. Artinya menilai apakah suatu opini adalah opini yang valid dapat diuji dengan memastikan apakah opini tersebut diperoleh melalui metodologi yang tepat terhadap data-data yang relevan. Sehingga walaupun metodologi yang dipakai sudah tepat tapi data yang diuji bukan data yang relevan atau valid, maka opini menjadi tidak valid.

\section{B. Aspek Pengetahuan Khusus (Specialized Knowledge)}

Rule 702, Federal Rule of Evidence menentukan bahwa suatu pendapat ahli merupakan bukti ilmiah jika didasarkan pada data atau fakta yang akurat, serta diperoleh dari prinsip dan

183 Pengadilan Negeri Jakarta Utara, Putusan No. 108/Pdt.G/2015/PN.Jkt.Utr., op. cit., hlm. 165. 
metode ilmiah yang dapat diandalkan. Di Indonesia, peraturan yang ada belum mengatur kriteria yang jelas terkait pendapat ahli, sedangkan kriteria yang ditetapkan dalam Pedoman Penanganan Perkara Lingkungan juga masih sangat luas. Pedoman, misalnya, belum mengatur tentang perlunya ahli memiliki pengetahuan khusus (specialized knowledge) yang sesuai dengan kebutuhan perkara.

Dalam perkara P.T. JJP, Penggugat menghadirkan Ahli untuk menjelaskan besar dan nilai kerugian lingkungan serta biaya pemulihan yang diperlukan. Majelis Hakim menerima penjelasan Penggugat tentang latar belakang dan keahlian khusus yang dimiliki oleh para Ahli serta kredibilitas laboratorium yang dipakai. ${ }^{184}$ Putusan Majelis Hakim juga sudah dengan jelas menerima penghitungan ganti kerugian yang disampaikan oleh ahli Penggugat.

Namun demikian, dalam menganalisis pertimbangan hakim tersebut dari aspek pengetahuan khusus, tulisan ini menganggap penting untuk membahas lebih lanjut bagaimana Majelis Hakim menerima keterangan ahli soal penghitungan ganti kerugian? kriteria apa yang dipakai oleh Majelis hakim untuk menilai bahwa ahli tersebut adalah ahli yang memiliki pengetahuan khusus?

Sementara itu, secara teori proses valuasi lingkungan terdiri dari berberapa tahap. 185 Tahap pertama adalah menjelaskan ruang lingkup dari analisis yang dibutuhkan (the scope of analysis required). ${ }^{186}$ Kedua, mengidentifikasi dampak terhadap lingkungan (identify all the

184 Prof. Bambang Hero Saharjo. M.Agr. telah memperoleh penunjukan dari Menteri Lingkungan Hidup berdasarkan Surat Penunjukan ahli Nomor SPA-03/Dep.V/LH/HK/12/2014 tanggal 31 Desember 2014 dan juga sebagai Kepala Laboratorium Kebakatan Lahan Fakultas Kehutanan IPB dan anggota Tim Panel Pakar Kebakaran Hutan dan Lahan ASEAN, Chair Souteast Wildlife NetworkUNISDR yang bernaung di bawah PBB. Sedangkan DR. Ir. Basuki Wasis, M.Si. adalah peneliti IPB dalam masalah kerusakan lingkungan khususnya kerusakan tanah gambut dan telah sering diminta sebagai ahli dalam penanganan kasus lingkungan oleh aparat penegak hukum.

185 Justice Brian J. Preston, Economic Valuation of the Environment, (makalah disampaikan pada Land and Environment Annual Conference, 28 May 2015, Manly, Australia, 13-17).

186 Ibid., hlm. 14. 
APLIKASI PRINSIP-PRINSIP TERKAIT BUKTI ILMIAH (SCIENTIFIC EVIDENCE) DI AMERIKA SERIKAT DALAM PEMBUKTIAN PERKARA PERDATA LINGKUNGAN DI INDONESIA

environmental impacts). ${ }^{187}$ Ketiga, mengkuantifikasi dampak yang telah diidentifikasi (quantify the environmental impacts). ${ }^{188}$ Tahapan terakhir adalah melakukan penghitungan keuangan (monetise the environmental impacts). ${ }^{189}$

Terkait dengan masalah diatas, SK KMA No. 36 No. 36/KMA/SK/II/2013 tentang Pedoman Penanganan Kasus Lingkungan sendiri membolehkan penghitungan kerugian lingkungan hidup dilakukan oleh ahli kerusakan lingkungan. Pada saat pembentukan, SK ini merujuk pada ketentuan Permen LH No. 13 tahun 2011 tentang Kerugian Lingkungan Hidup Akibat Pencemaran dan/atau Kerusakan Lingkungan Hidup terkait siapa yang dapat melakukan penghitungan kerugian. Permen ini sudah diganti oleh Peraturan Menteri Lingkungan Hidup (Permen LH) No. 7 tahun 2014 tentang Kerugian Lingkungan Hidup Akibat Pencemaran dan/atau Kerusakan
Lingkungan Hidup yang masih memuat pengaturan pengaturan yang sama, yakni ahli pencemaran dan/atau kerusakan lingkungan dapat melakukan penghitungan kerugian lingkungan. 190

Kemudian, pasal 4 Permen LH No. 7 Tahun 2014 tentang Kerugian Lingungan Hidup Akibat Pencemaran dan/atau Kerusakan Lingkungan Hidup juga membedakan antara ahli pencemaran dan/atau kerusakan lingkungan dengan ahli valuasi ekonomi lingkungan hidup. Berdasarkan ketentuan ini, pertanyaan kritis diatas dapat diuji dengan beberapa pertanyaan lanjutan sebagai berikut.

Pertama, Rule 702 menyatakan bahwa seorang saksi yang memiliki keahlian berdasarkan pengetahuan, keterampilan, pengalaman, pelatihan atau pendidikan yang ia miliki, dapat menjadi ahli dan mengemukakan

187 Ibid., hlm.15.

188 Ibid., hlm.16.

189 Ibid., hlm. 17.

190 Indonesia, Menteri Lingkungan Hidup, Peraturan Menteri Lingkungan Hidup tentang Kerugian Lingkungan Hidup Akibat Pencemaran dan/atau Kerusakan Lingkungan Hidup, No. 7 tahun 2014, Pasal 4. 
pendapatnya di pengadilan. Apakah ahli kerusakan lingkungan tersebut memiliki pengetahuan, pengalaman, pendidikan serta pelatihan terkait dengan substansi yang ada pada tahapan-tahapan tersebut? Kedua, apakah penghitungan ganti kerugian yang disampaikan oleh ahli kerusakan lingkungan telah menguraikan keempat tahapan diatas?

Pertanyaan-pertanyaan diatas perlu dijawab melalui penelitian yang lebih mendalam dalam kerangka yang lebih luas - perbandingan sistem penilaian bukti ilmiah dalam kasus lingkungan di Indonesia dengan dengan sistem di Amerika serta negaranegara lain yang dianggap menarik. Terkait dengan aspek pengetahuan khusus, salah satu aspek penelitian dapat ditekankan pada penentuan kriteria serta tahapan apa yang perlu dilakukan oleh seorang ahli dalam melakukan valuasi lingkungan akibat kebakaran hutan. Sehingga beberapa ahli mungkin perlu dilibatkan untuk suatu alat bukti terkait bukti ilmiah. Pada akhirnya, kemampuan hakim untuk memastikan apakah pendapat ahli tersebut dilakukan dengan metodologi yang valid menjadi salah satu faktor kunci dalam menilai kredibilitas dari suatu bukti ilmiah. Hal ini mensyaratkan kemapuan hakim yang memadai tentang sains yang relevan (sufficient level of relevant scientific knowledge), pedoman yang jelas dan metode pelatihan yang komprehensif terkait bukti ilmiah.

\section{Penutup}

Kriteria Daubert memuat prinsipprinsip penting dalam melihat apakah suatu bukti imiah adalah bukti yang dapat diandalkan. Secara umum pengaturan hukum di Indonesia sudah memuat prinsip-prinsip dari kriteria Daubert sebagaimana telah diuraikan diatas. Selain itu prinsip-prinsip tersebut juga telah secara umum digunakan dalam penanganan perkara perdata lingkungan. Namun demikian, hal ini belum dapat dianggap cukup. Terdapat berberapa tantangan yang dihadapi di lapangan. Tulisan ini menyimpulkan bahwa tantangan yang ada di lapangan adalah bahwa aturan yang ada selama ini belum 
memberikan panduan yang lengkap untuk menilai validitas bukti ilmiah yang diajukan dalam persidangan dan pengetahuan khusus yang dimiliki oleh ahli. Untuk itu, peraturan dan pedoman tentang pembuktian dalam perkara lingkungan di pengadilan perlu disempurnakan. Perhatian khusus perlu diberikan pada aspek penggunaan metode ilmiah dalam menentukan validitas bukti ilmiah, serta pendapat ahli yang harus didasarkan oleh pengetahuan khusus. Aspek-aspek lain yang relevan dan penting perlu diidentifikasi lebih lanjut secara komprehensif.

Namun demikian, perlu diakui bahwa penyempurnaan peraturan yang diusulkan tersebut akan memberikan tantangan tersendiri bagi hakim. Pengaturan yang detail berarti mensyaratkan hakim untuk memiliki pengetahuan ilmiah (scientific knowledge) yang memadai. Tentunya hakim tidak diharapkan untuk dapat memiliki pemahaman layaknya seorang ilmuwan. Namun, hakim diharapkan mampu merumuskan pertanyaan-pertanyaan penting dalam menilai validitas bukti ilmiah dan kualifikasi saksi ahli, agar dapat memberikan pendapat ilmiah yang relevan dengan perkara. Oleh sebab itu, penguatan hukum tersebut juga perlu didukung dengan adanya pelatihan khusus bagi hakim, dengan materi dan metode yang tepat. Metode yang dipakai harus dapat membantu hakim dalam memilah dan memilih bukti ilmiah yang relevan, dan menerapkan ke dalam suatu perkara. 


\section{DAFTAR PUSTAKA}

\section{Peraturan Perundang-Undangan}

Federal Rules of Evidence, Rule 702, diundangkan pertama kali pada tahun 1975.

Indonesia. Undang-Undang Hukum Acara Pidana. UU No. 8 Tahun 1981. LN No. 76 Tahun 1981, TLN No. 3258.

Indonesia, Mahkamah Agung, Keputusan Ketua tentang Pedoman Penanganan Kasus Lingkungan, SK KMA No. 36/KMA/SK/II/2013.

Indonesia, Menteri Lingkungan Hidup,

Peraturan Menteri Lingkungan Hidup tentang Kerugian Lingkungan Hidup Akibat Pencemaran dan/atau Kerusakan Lingkungan Hidup, No. 7 tahun 2014.

Kitab Undang-Undang Hukum Acara Perdata [Het Herzein Inlandsch Reglement/Reglemen Indonesia yang Diperbaharui], diterjemahkan oleh Tim Visi Yustisia, (Jakarta, Visi Media Pustaka, 2015).

\section{Putusan Pengadilan}

D.C. Cir. Frye v United States 293F (1923), 1014.

11 $1^{\text {th }}$ Cir. United States v. Else, 743 F.2d 1465, 1474 (1984).

$5^{\text {th }}$ Cir. Christophersen v. Allied-Signal Corp, 939 F.2d 1106 (1991), cert. denied, 112 S. Ct. 1280 (1992).

Supreme Court of The United States. Daubert v Merrell Dow Pharmaceuticals, Inc. (1993) 113 S. Ct 113 S. (1993).

D. Tex. Cano v. Everest Mineral Corp., 362 F. Supp.2d 814 (2005).

Mahkamah Agung, Putusan No. 651 K/PDT/2015.

Pengadilan Negeri Jakarta Utara, Putusan No. 108/Pdt.G/2015/PN.Jkt.Utr.

Pengadilan Negeri Jakarta Selatan, Putusan No. 456/Pdt.GLH/2016/PN.Jkt.Sel.

Pengadilan Tinggi Jakarta, Putusan No. 727/PDT/2016/PT.DKI.

\section{Buku}

Ali, Achmad dan Heryani, Wiwie. AsasAsas Hukum Pembuktian Perdata. edisi 1. Jakarta: Kencana Perdana Media Group. 2012. 
APLIKASI PRINSIP-PRINSIP TERKAIT BUKTI ILMIAH (SCIENTIFIC EVIDENCE) DI AMERIKA SERIKAT DALAM PEMBUKTIAN PERKARA PERDATA LINGKUNGAN DI INDONESIA

Glaubber, Ann Jeannette. et. al., “Kerugian dari Kebakaran Hutan: Analisa Dampak

Ekonomi dari Krisis Kebakaran Tahun 2015." Laporan Pengetahuan lanskap

Berkelanjutan Indonesia No.1.

World Bank Group. 2016.

Mayo, Deborah G. dan Rachelle D. Acceptable Evidence. New York: Oxford University Press. 1991.

Popper, Karl R. The Logic of Scientific

Discovery. edisi 2. New York:

Routledge. 1968.

Pring, George and Pring, Catherine. Greening Justice: Creating $\mathcal{E}$ Improving Environmental Courts $\mathcal{E}$ Tribunals. The Access Initiative. 2009.

Environmental Courts E Tribunals

- A Guide for Policy Makers (UNEP) | ELAW (2016).

\section{Artikel}

Bernstein, David E. “The Admissibility of Scientific Evidence after Daubert v. Merrell Dow
Pharmaceuticals, Inc." Cordozo Law Review 15 (1993).

Bishop, Katherine. "Science Advance so Quickly Nowadays. We can't just Count Scientific

Cranor, F. Carl, “A Framework for Assessing Scientific Arguments: Gaps, Relevance and Integrated Evidence. "Journal of Law $\mathcal{E}$ Policy, Brooklyn Law School Vol. 15 (7) (2007).

Egesdal, M. Steven, “The Frye Doctrine and Relevancy Approach Controversy: An Empirical Evaluation," 74, Geo.L.J. (1986).

Giannelli, Paul C. "The Admissibility of Novel Scientific Evidence: Frye V. United States, A Half Century Later." Columbia Law Review Vol. 80 No. 6. (1980).

Hutchinson, Clifton T. dan Ashby S. Danny. “Daubert v. Merrell Dw Pharmaceutical, INC.: Redefining the Basis for Admissibility of expert Scientific Testimony." Cordozo Law Review 15 (1993).

Markus, L. Richard. "Discovery Along the Litigation/Science 
Interface." Brooklyn Law Review Vol. 57 (1991).

Muirden, April. dan John Bailey. "Presenting Scientific Evidence in Environmental Court Cases: How Science and Law Meet" Environmental Planning and Law Journal Vol. 25 (2008).

Nardi, Jr, J. Dominic, "Do Indonesian Judges Need Scientific Credibility? Indonesia v. PT. Newmont Minahasa Raya and the Use of Scientific Evidence in Indonesian Courts." Georgetown International Environmental Law Review Vol. 21 Issue 113.

Park J. Keum, “Judicial Utilization of Scientific Evidence in Complex Environmental Torts: Redefining Litigation Driven." Fordham Environmental Law Review Vol. 7 No. 2 (1996).

Preston, J. Brian. "Science and the Law: Evaluating Evidentiary Reliability." (tulisan disampaikan pada the Australian Conference of Planning and Environment
Courts and Tribunals, Adelaide, 4-7 September 2002).

. "Economic Valuation of the Environment." (makalah disampaikan pada Land and Environment Annual Conference, 28 May 2015, Manly, Australia). Thornton, John I. "Uses and Abuses of Forensic Science." American Bar Association Journal. Vol. 69 Issue 3. (1983)

\section{Lain-Lain}

Cancer Council of Australia, "What is Oncology?"

https://www.cancer.org.au/he alth-professionals/oncology/, diakses 10 September 2018. Kamus Besar Bahasa Indonesia Daring, https://kbbi.web.id/sains, diakses 10 September 2018.

Katherine Bishop, Science Advance so Quickly Nowadays. We can't just Count Scientific Noses', Leap of Science Create Quandaries on Evidence, N.Y. TIMES, April 6, 1990.

$\begin{array}{cc}\text { MVT, “Hakim Seringkali } & \text { Abaikan } \\ \text { Bukti } & \text { Ilmiah," }\end{array}$


http:/ / www.hukumonline.com

/berita/baca/1t4d4cf9774f064/h

akim-seringkali-abaikan-bukti-

ilmiah-,_diakses pada 23 Juli

2018.

Wawancara dengan Justice Brian J.

Preston, Ketua Pengadilan Land

\& Environment Court, New

South Wales, Australia, 7 Maret 2018.

Wawancara dengan Raynaldo
Indonesian Center for

Environmental Law pada tanggal 5 Juli 2018.

Wawancara dengan Fauzul Abrar, S.H pada tanggal 17 Juli 2018.

Yenrizal, “Opini: Berkaca Pada Putusan Kasus PT. BMH", http://www.mongabay.co.id/2 016/01/13/opini-berkaca-padaputusan-kasus-pt-bmh/, diakses pada 12 September 2018.

Sembiring, Peniliti pada 